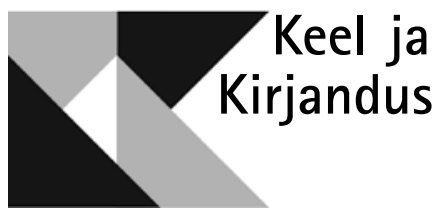

\title{
AIROOTSI - LAURI PILTERI KIRJANDUSLIK OMAILM
}

\author{
BRITA MELTS
}

$\mathrm{T}$ õlkijana on Lauri Pilter tutvustanud üht huvitavat nähtust, nimelt „regionalistlikku ehk „kohaliku koloriidi” kirjandust” (Pilter 2013), ja sarnase nähtuse alla sobitub ka tema enda proosalooming. Esikteosest „Lohejas pilv" alates on ta sidunud oma kirjanduslikke arendusi subjektiivselt, mõnel juhul lausa intiimselt tähenduslike paikadega, mille võrgustikust on dokumentaalsuse ja fiktsiooni põimingus kujunenud ajapikku loominguline omailm. See on teadlikult ehitatud kirjanduslik maailm, kus teosest teosesse „korduvad samad kohad ja tegelased” (Velsker 2014). Sihipärasus ja isiklikest eelistustest lähtuv reaalse ümbruse elementide, kohtade, elanike esiletõstmine, kordamine või välistamine ongi omailma alus. Semiootilisest Umwelt'i käsitlusest (nt Uexküll 2012) tõukuvalt olen kirjanduslikku omailma määratlenud poeetilis-subjektiivse maailmana, mis ühendab endas tõeluse ja väljamõeldise, omaeluloolisuse ja ilukirjanduslikkuse. See kätkeb nii tekstides loodud maastikke kui ka nende eeskujuks olevat reaalset, enamasti kirjaniku kodupiirkonnaga kattuvat keskkonda, samuti autori geograafilist taju, tema siseilma, ümbruskonna objektide sihipärast valikut ning tema kujutlusi ja selle kõige projitseeritust teostesse (mina)tegelase ruumi kuuluvate eksplitsiitsete ja tähenduslike elementide kaudu (Melts 2013: 393, 2014: 511-512). Seega, omailma puhul on kirjeldatava maailma kese kirjanik ise oma loomingulise subjektsusega: autor kujundab teda ennast ümbritseva vahetu tegeliku ja talle tähendusliku keskkonna loominguliseks omailmaks (Melts 2014: 510), millele võidakse anda metafoorne või väljamõeldud nimi, nagu seda on Pilteri loo- 
mingu kaasaegsed Andrus Kasemaa Poeedirahu või Tõnu Õnnepalu Paradiis, kindlustamaks ja piiramaks oma isiklikku ruumi kõigile avatud maailma sees.

Ka Pilteri isiklikest kohtadest tähenduslikemad moodustavad kokku fiktiivse toponüümiga kirjanduspaiga - Airootsi, ${ }^{1}$ millele võib tegelikul maastikul otsida vastet „Lohejas pilves” esinenud Noarootsi poolsaarelt Läänemaal - Noarootsi-nimelisena algabki ühe ja sama tegevusruumi kujutamine tema loomingus. Aegamisi imbub aga sellesse maailma tegelikust geograafiast võoritavaid ja omavahel segunevaid kohanimesid, ${ }^{2}$ mis hajutavad fiktiivse nimega ilukirjanduskoha ja päris geograafia vahele võrdusmärgi tõmbamise võimalusi. Küllap seejuures inspireerib toponüümset mängu ja ebamäärasust Noarootsi segase päritoluga nimi isegi: selle muutumislugu rannarootsi Nucköst (esimestes mainimistes Nucke ja eestlaste pruugis ka Noka või Nukomaa) tänapäevaseks Noarootsiks on kirev (vt Lagman 1964: 14-17) ja tänini lópuni seletamatu.

Ent geograafilise Noarootsi lokaalkoloriit Pilteri loomingus on äratuntav ja tugev, ilmselge alus Airootsi-nimelise omailma kujunemisele. Artiklis vaatlengi erinevate maastikumõtestuste ja kirjandusliku omailma võtmes Noarootsi loomingulisi kaardistusi ja väljamõeldud toponüümiga tähistatud Airootsiks kujunemist. Analüüsis lähtun laias laastus neljast Pilteri teosest: kolmest romaanist lühijuttudes „Lohejas pilv” (2004), „Retk Rahemäkke” (2010) ja „Aerudeta köisraudteel” (2012) ning Airootsi-kuvandiga raamitud jutukogust "Vilekoor ja teisi jutte" (2014), millest just esimene ja viimane teenivad siinse artikli raames põhjalikumat pilku. Eesmärk on tuua välja see, kuidas visuaalse selektsiooni ning sihipärasuse alusel kujutatakse reaalset maastikku kirjanduses, kuidas sellest kujuneb omailm, mis on selle põhilisteks iseloomustajateks ning kuidas terviklikult ja isiklikult läbitunnetatud mentaalset ruumi hakatakse kohakujutustega taas mosaiigistama, tuues ükshaaval välja omailma eredaimaid ning tähenduslikemaid elemente.

Kõrvutused mõne teise Noarootsi või ka ulatuslikumalt Läänemaa kirjeldusega on vältimatud, mistõttu hakatuseks olgugi siin toodud üks avaram kohakuvand, millest võib noppida Pilteri Airootsi uurimiseks tarvilikke märksõnu: ,„Lahja põld ja kadakane karjamaa...” Küsi, keda tahad, missugust maakonda luuletaja on mõelnud, ja ta vastab kõhklemata: Läänemaad" (Ristikivi 1996: 23). Nõnda alustas Läänemaalt pärit Karl Ristikivi oma esseed „Läänemaad otsimas" ja mõne lõigu pärast teenib sellesama maakoha kirjeldus dramaatilisemaidki sõnu:

...võõrale rändajale jääb mulje „maailma kõige sügavamalt melanhoolsest maastikust", nagu seisis kord ühes reisikirjelduses. Eriti kui on hilissuvi või sügis, kui udu madalatelt lodumaadelt ja soostunud rannajärvedest levib üle lagedate karjamaade ja põldude, kus lõikus on kogutud harvadeks kuhilateks ja rõukudeks ja kadakasuitsu iseloomulik mõrkjas ving võõrapäraselt puudutab ninasõõrmeid. Kuidagi mahajäänud ja tühi tundub siis Läänemaa loopealne, ega suuda seda tunnet leevendada ka sumbküladeks koondunud või vooreharjale tee äärde reastunud hallid, vanadusest kühma vajunud, peaaegu mustunud rookatusega talud (Ristikivi 1996: 24).

\footnotetext{
${ }^{1}$ Siin võib ära tunda loomingulise kombinatsiooni Aibolandist, rannarootslaste omanimetusest nende asustusalade kohta Eesti rannikul ja saartel, ja Noarootsist.

${ }^{2}$ Näiteks on lähim linn Haapsalu teisenenud Hoosaliks, Österby kannab mõnel pool Eistorbi nime, küllap on Sutlepa merest saanud Nislepa ja otsekui konkreetsuse vältimiseks tähistab viimane ka Noarootsi vallakeskust Pürksit jne.
} 
Ristikivi kirjeldab siin maastikku, mida ta oli tundnud oma lapsepõlves ning otsinud ja taastunnetanud loomingus. „Aga see on ainult lääneranniku üks pale" (Ristikivi 1996: 24), teab ta samas, ning jätkab hoopis paikkonna „omamoodi ilu" ja kütkestavuse äramärkimisega. Nii ei jäänud ta üksnes askeetliku Läänemaa otsinguile, vaid jõudis oma loometeel ka selle võluva poole ülesleidmiseni, mis eeldab rohkema tajumist kui pelk silmaga haaratav vaateväli. „Rohtaias” leidub episood, kus suveks maale jõudnud Juulius Kilimit loobub viimasel teelõigul vankrisõidust, et uidelda loogeldi ümber põõsaste kulgevail jalgradadel. Nõnda märkab ta metsa all hiliskevade kõige rikkalikumaid õisi, tunneb õhtuselt niisket ja karedat rohtu kõditamas jalataldu, kuni intensiivselt meeleline maastik äratab temas enneolematu tunde: „Ja kuigi selles kõiges vaevalt midagi oli Kreekamaa loorberihiitest ja sealsetele inimestele kogu see olemine siin oleks kindlasti paistnud väga külm, pime ja barbaarne, Juulius Kilimit tundis ometi, et see siin oli niisama hea kui Arkaadia" (Ristikivi 2008: 52). „Rohtaia” peategelase kodumaastik ei ole küll täpselt lokaliseeritud. Selgelt Läänemaalt pärinesid aga juba Ristikivi Tallinna-triloogia kahe esimese teose kesksed tegelased, Läänemaaga olid seotud ka noor seikleja Ristikivi „päriskirjanduse” lävepakus „Viikingite jälgedes” (1936) ning resigneerunud Kaspar kirjaniku luigelauluks jäänud „Rooma päevikus” (1976) - ainuüksi sellestki nähtub, et läänemaisus moodustab kujundliku raami Ristikivi loodule tervikuna. Nii pole kahtlust, et Kilimiti kohta käiv poetus „,[s]ündinud seal kuski üsna all" (Ristikivi 2008: 23) tähistab ilmselgelt ja üheselt sedasama Läänemaad, täpsemalt selle lõunasoppi mere lähedal (vt Nirk 1991: 114), kus möödus kirjaniku lapsepõlv. Ning „Rohtaia” episoodis, milles „Arkaadia ja kodupaik on üheks hapraks hetkeks võrdseks saanud” (Ruutsoo 1988: 80), on kirjanik sõnastanud oma kodususe tunde ning füüsiliselt läbi tunnetatud ja seeläbi personaalselt oluliseks saanud läänemaise maastiku leidmise ei millegi muu kui kujundliku omailmana, unistuste Arkaadiana.

Sarnane ringjas järjepidevus ning läbivus kirjaniku kogu loomingu lõikes on tunnuslik Pilterile: sama järjekindlalt on ta oma loomingus riivanud, otsinud ja leidnudki Ristikivi Läänemaale lähedast ja mõnel määral sarnanevatki piirkonda. Võttes Ristikivi kujutusist märksõnalisteks teetähisteks otsimise, läbi maastiku jalutamise/uitlemise ja millegi subjektiivselt ning aistiliselt tähendusliku leidmise, samuti vastandlikkusi ehk helget idülli ja metsikut süngust põimiva Arkaadia-motiivi (vt Kronberg, Melts 2012) ülekande kodumaastikule, liikugem nüüd Ristikivi Läänemaa-sopikesest veidi eemal olevasse nurgakesse, Läänemaa loodeserva jäävale Noarootsi poolsaarele, kus paikneva tegeliku maakoduga seotud kogemused on kandunud Pilteri ilukirjanduslikku maailma.

\section{Kohale jõudmine}

Läänemaaga seotus ulatub nii Pilteril kui ka tema teoste peategelas(t)el juba nelja dekaadi tagusesse aega: sinna 1975. aastal jõudmise alguspunktiks on kolmeaastase poisikese („Lohejas pilves” Lavrani, „Vilekoori...” jutukogus Laratsi) elupaigaks saanud Haapsalu, ent peagi jõuab pere maamaja otsingutega ka Noarootsi. „Loheja pilve” üks tegevusliin leiab aset sealse gümnaasiumi ümbruses, mis kohana aga pole tähenduslik ja jääb anonüümseks. Oluliseks 
saab aga mõne kilomeetri kaugusel, merele lähemal asuv maakodu: raamatus kirjeldatakse esmalt selle otsimist ja ostmist 1983. aasta alguses (Pilter 2004: 75), siis ka selle tasapisi avastamist ja kujundamist, jõudmata küll avarama haardega isikliku Airootsi äratundmiseni. Maakodu koht poolsaare servas, kuhu pääseb kahel eri viisil, nii meritsi üle pahiseva lahe kui ka mööda kidura taimestiku ja kadakatega palistatud maanteed, on esialgu lihtsalt ja üldiselt „Noarootsi maamaja” ning piirkonna tundmaõppimine algab maja hoovist. Jutustaja/tegelase vaateväli avardub aga peagi: pärast koduhoovi kaardistamist (vt Pilter 2004: 70) võtab ta ette maakoha täpsema ja konkreetsema määratlemise, ulatuslikuma ala detailse kaardistamise, mille üksikasjalisus ei asetu aga üleüldistele teadmistele. Selles ilmneb juba kohastumine ja kohanemine: maamajast tõmmatakse ühendusjooni lähiümbruse spetsiifiliste ja põgusal pilgul tähtsusetute punktideni, mis on olulised just kohaliku elu seisukohast, ent milles puudub suurem erakordsus ja silmapaistvus eemalt tulijale. Maja sätitakse sellega külaelanike argielu foonile, tutvustatakse naabreid, nende tegevusalasid ja sidemeid - see on Pilteri edasist loomingut silmas pidades väga märgiline vahetusse igapäevase tegevuse välja ning kogukonda sisseelamise tähis:

Küla keskkohani oli meie maja juurest seitsesada meetrit. Vahele jäi avar kolhoosipõld. Keskuses paiknes kunagine tuletõrjekuur, millel oli hallidest laastudest katus ja mille sees asus möödunud ajastu reliktina jämeda lülilise voolikuga tuletõrjepump ja seina küljes olid külaelanike postkastid. Kuuri kõrval paiknes bussipeatus. Sellest ühele poole jäid maja, mille mõni aasta hiljem ostis endale Ilmar Kunnas, ning maja, milles elas koos oma purjutava naise ja väikese pojaga Kalev, kes käis hiljem meil sulaseks, ja mille teine pool kuulus mehele, keda me kutsusime mesinikuks, sest igal sügisel müüs ta naabritele, ka meile mett. Kuurist teisel pool elas Kunnase vanem vend August oma naise Dunjaga, kes oli Venemaalt pärit ja võis olla rahvuselt komitar, sest tal olid Siberi põliselaniku näojooned (üks poeg oli neil Venemaal kõrge auastmega sõjaväelane), ja natuke maad kaugemal elas mees nimega Arvi, kes ajal, kui meil veel kaevu polnud, tõi meile traktori järel tsisterniga põllu niisutamiseks vett ja keda me seetõttu hakkasime kutsuma Veemeheks. Üle põllu meie juurde kulgeva tee ääres kasvas kummeleid, rukkililli ja üksikuid kibuvitsapõõsaid ning meie maja lähedal isegi üks pisikesi vilju kandev õunapuuke. Meie hoovi tagant algas mets; sinna suunduv tee läbis otse meie õue, õieti polnudki see siin enam tee, vaid lihtsalt traktoriroopad (Pilter 2004: 72-73).

Ehkki täpne nii üksikasjades kui ka suunamõõtmeis, jääb tähendusliku ala lokaliseerimine „Lohejas pilves” ometi hajusaks, sest nimetatud märkide juures hoidutakse neid tegelikele kaartidele kinnistavatest kohanimedest ning nii ütlevad need midagi üksnes kohta tundvatele teelistele ja lugejatele - nii maamaja, selle lähem ümbrus kui ka terve poolsaar juba märksa ulatuslikuma alana on kokku üksainus ja üldine Noarootsi. (Justkui kogemata, anonüümsusest hajameelselt üle libisedes konkretiseerub koht Einbi ja Österby nimetamisega ainult „Loheja pilve” 172. ja 177. leheküljel.)

Nii kuulub Läänemaa üks nukake Pilteri loomingus ettevaatlikule avastamisele, nii et topograafilise visiooni (vt Eco 2009: 85) kujunemine, ümbrus- 
konna tunnetus ja hoomamine kätkeb juba eos etapilisust või episoodilisust. Esialgsetes kirjeldustes jäädakse kõike justkui ebalevalt ja eemalt silmitsema: „Loheja pilve” Noarootsi, nii reaalsuse kirjanduslik kujutus kui ka hilisema loomingulise omailma alus, on pelk laotus ${ }^{3}$ sinna sisserännanud tegelase ümber; selles laotuses liigutakse, seda uuritakse ja aistitakse, ent subjektiivsete tähenduste väli, kogemuste ja eelistuste võrgustik on veel ahas ja avastamisel - mentaalne, puhtsubjektiivne ruum jääb alles varju. Keskkonna tunnetamisviise määrava kogemuste struktuuri kujutamine saavutab selles raamatus intensiivsuse muudes asjaoludes (psühholoogilistes süvaloodimistes, juudiküsimustes ja inimsuhtlemise puntrais), mitte ruumitajus, nii et esmastes lugejani vahendatud kontaktides Noarootsi ehk hilisema Airootsiga võib näha alles üksikute tajupiltide sidumist põgusaks ja hajusaks miljööks, mille terviku läbitunnetamiseks alles asutakse teele. Kuid tajupiltide sidumine juba toimub - „visuaalse selektsiooni kaudu”, kui siin tugineda Juhan Maistele: „Visuaalse selektsiooni kaudu eristame maailmast olulise, filtreerides pidevalt liikuvast ja muutuvast pildist välja osad, mille peatamise kaudu on meist igaüks kui kunstnik võimeline looma maailmast tervikliku ettekujutuse - looma maastiku" (Maiste 2011: 162).

Visuaalse selektsiooni järgmine samm kinnitab kanda metsikus looduses, ebaõdusal maastikul, sest pärast maja ja aia tundmaõppimist, vahetu ümbruse kaardistamist minnakse metsa. „Loheja pilve” kõige märgilisem maastikukuvandi episood leiab aset peamiselt neljal leheküljel (vt Pilter 2004: 172-175) raamatu viimases veerandis. Tegelane „asub teele” ning teeb nähtavaks kohtade võrgustiku, mis on oluline omailma raames: ta võtab selgelt subjektiivsetel eesmärkidel ette sihipärase kohtumise maastikuga, tegeleb lähikonna tundmaõppimise ja isiklikku tähelepanu köitvatele maamärkidele osutamise ja selle abil oma tähendusliku ruumi piiritlemisega. Ta suundub külavaheteest lõuna pool laiuvasse metsa, uurib lõunast merega piirnevat metsamassiivi, „mida ainukese inimtegevuse märgina lõikas läbi elektriliini ümber raiutud siht" (Pilter 2004: 173). Ta silmitseb sellesama metsamassiivi idaservas oja; seirab kadastikke „läbisegi lehtpuudega” ning lääne poole jäävaid kasetukakesi; leiab kohti, kus metssead olid kilomeetrite kaupa maad tuhninud, ning jõuab oma maastikukaardistusega umbes kilomeetri jagu laiuva kõrge metsa alla, kus „puud varjutasid valguse nii jäägitult, et alusmetsa peaaegu polnudki" (Pilter 2004: 173). Niisuguses metsalises, tokerjas ja kohati lausa sünges keskkonnas uitlemise episood aga jätkub, et laiendada visuaalset selektsiooni nii taimestiku uurimisega kui ka võsastiku ja roostiku piiril metsloomade aimamisega ning et viimaks liita sellesse puhtisiklikku tundlemist: nähes mere pool „paiku, millest mul oli eredaid romantilisi mälestusi” (Pilter 2004: 173). Seega ei paku maastik, mida tegelane intensiivselt läbi tunnetab, mitte ainult lopsakat metsikust, vaid ka poeetilisi ja tundelisi elamusi. Võimalikult erineva maastikukogemuse kirjeldamist ei ole kammitsenud geograafilised või topograafilised mõõtmed, vaid see on rajatud ka emotsionaalsele ja psüühilisele skaalale, jõudes niiviisi kahe arkaadialiku maastikutüübi kontrastsete tajumisteni.

${ }^{3}$ Vrd geograafilise käsitlusega: maastik on kui „laotus, mida inimene tajub ja milles ta liigub" (Oja 2008: 127). 
Olen varem käsitlenud (vt Kronberg, Melts 2012) kaht vastandlikku ja kultuuriajaloos vaheldumisi domineerivat Arkaadia tüüpi, mis nii mõnelgi juhul on olnud tagasiviidavad samale maastikule: ühel juhul on Arkaadia tokerjas, metsik, hämar, ihade tume salu, hulluse ja surma labürint, ürgse „paanilise hirmu" ja ettearvamatute elamuste paik; teisal jällegi idülliline, kultiveeritud, sile ja hele, helge bukoolilise rahu ning vabaolu paik (Schama 1995: 517, 522, 570). Ka Pilteril leiab hele, õrn ja kütkestav kohamulje tee läbi metsiku, tumeda ja räämas maastiku, kui ta samas episoodis jätkab ümbruskonna mentaalset kaardistamist: jõudnud kord ka mereäärsele lagedale madalikule, „millel kasvas mitmesuguseid vee- või niiskete alade taimi”, avastab uitleja selles hoopis midagi troopikat meenutavat ning sinendavais kaugusis peituvaid saladusi (Pilter 2004: 174). Sellega on metsik, imelik ja ebaõdusalt kummastav mulje maastikust korraga üle läinud ahvatlevalt troopiliseks, peibutavalt salapäraseks - nii nagu Ristikivi pilgus ülenes „melanhoolne maastik” aeg-ajalt kaugeks ja ebatõeliseks igatsuste Arkaadiaks, teisenevad ka Pilteri meelelised elamused lausa eksootiliseks: „Kadakate vahel laius suuri tühje rohulappe, kus lojused olid kunagi söönud. Oli kummaline, et nende muidu haljendavate lappide sees (mille serval kasvas pääsusilmi) oli südasuvel peaaegu nelinurkseid kollakaspruuniks kuivanud või kõrbenud laike; kohati oli rohi neis paigus lausa oranž, nii kaugele kui silm kadakate vahel seletas, kõlkusid ja sahisesid tuules oranžid rohukõrred, mitte ühestki suunast polnud näha ainsatki inimtsivilisatsiooni märki (sest kadakad varjasid vaate), valitses täielik vaikus peale üksiku ritsikasirina”; seesugune maastik meenutas „Hemingwayd, meenutas tema savannide ja safarite Aafrikat: oma eksootilises värvidegammas ei tundunud ta üldsegi põhjamaine, vaid mõjus nagu Henri Rousseau naivistlikud troopikamaalid, nagu paras paik kokkupuuteks lõviga või metslaste suguharuga. Tuul, mis sellel rusketoonilisel maastikul puhus, oli mahe ja paitas mu põski” (Pilter 2004: 174-175).

Siin on kõik aistingud, helid, värvid, lõhnad vormunud ainulaadseks tervikuks, mis omailma projitseeritult moodustab ühtse ja läbinisti isikliku tajupildi (vt Uexküll 2012: 142) ning on aluseks ühe ja sama piirkonna tunnetuslikule variatiivsusele. Ent tuleb tähele panna, et just u it aj a maastik on niivõrd varieeruv, sest selles episoodis kujutabki Pilter oma tegelast jalutajana - üksildase jalutajana, nagu ka Ristikivi tegelane eraldus teekaaslasest, et omaette jõuda maastiku kehalise tunnetamiseni. Paradoksaalselt ei ole niisuguses keskkonnakogemuses üksildus mitte lahutavaks, vaid liitvaks teguriks, sest üksildus ,heidab kogu olemasolu valla kõigi asjade olemuse avarasse lähedusse" (Heidegger 1989: 295) ning avab meeled kõige olulisemate, egotsentriliselt tähenduslikemate elementide tajumisele ümbritsevast. Niisuguses rännakus, üksinduses retklemises ei ole maastik enam pelk laotus, mida tajutakse ja kus liigutakse, vaid see avaneb esteetilistele naudingutele ning juhib maastiku „tuunitise” kogemiseni, kui kasutada loovat maastikku mõtestanud Martin Heideggeri väljendit, ${ }^{4}$ mille ta esitab vastandina maastiku objektilise-

\footnotetext{
${ }^{4}$ Essees „Loov maastik” sõnastab Heidegger maastiku põhjaliku tundmise ja isiklikuks, omamaastikuks tunnetamise nõndaviisi: „Ma kogen ta [maastiku - B. M.] tuunitist, päevitist-öist muutumist aastaaegade suures tulekus ja minekus. Mägede raskus ja nende ürgkivistu tugevus, nulgude aeglane kasvamine, õitsvate mägikarjamaade hiilgav lihtne ilu, mägioja kohin kauges sügisöös, sügavasse lumme tuisatud väljade karm lihtsus - see kõik surub ja tungib ja väreleb läbi argise olemise" (Heidegger 1989: 293-294).
} 
le, põgusast idüllist kantud tajumisele ehk „külalise ja suvevõõra vaatlevate silmadega" nägemisele (Heidegger 1989: 293). Pilteri kujutuses on küll tegu veel objektilise ja hetkelistest meeleoludest lähtuva maastikumuljega ning kindla peale Noarootsi-nimelise kohaga, mitte puhtisiklikku tähendusvälja kandunud Airootsiga, kuid juba väärib tähelepanu, kui täpselt, intensiivselt ja mitmekülgselt on oluline ruum kaardistatud „Lohejas pilves” - ilmakaarte, erinevate detailide vaheliste kauguste, spetsiifiliste objektide esiletõste, taimestiku liigiti eritlemise, meeleliste elamuste sisendusjõulise kirjeldamise ja poeetilise küllusega. Nii et loomingulisi metsi-maastikke semiootiliselt uurinud Umberto Ecolt sõnu laenates: „...võime lugejatena eristada iga tee väiksemaidki üksikasju. Ütleksin enamatki: me kogeme kõiki puuteaistinguid, mida kogeksime, kui neilsamadel kruusakividel marsiksime" (Eco 2009: 86).

Noarootsi-nimelist paika ei saa veel pidada sihipäraselt kujundatud omailmaks, kuid juba eristuvad selgelt selleks tarvilikud kolm ruumiüksust, mis vastastikku põimuvad ja üksteist täiendavad: mõjuruum, kompimisruum ja nägemisruum (vt Uexküll 2012: 90). Mõjuruumi ehk „liigutuste mänguruumi” kuuluvad subjektiivsed suunaaistingud ja vahemaid mõõdistavad liigutussammukesed, samuti konkreetsed suunad (paremale ja vasakule, üles ja alla, ette ja taha) ning üldkehtiv, kõikide ruumimääratluste aluseks olev koordinaatsüsteem. Kompimisruumi ehituskiviks on aga paigalseisev suurus, nimelt koht, ning kohaseoste võrk moodustab kompimisruumi. Ja viimaks annab nägemisruum omailmale horisondi (Uexküll 2012: 90-91, 95, 98). Kõik nimetatud ruumiüksused avarduvad aegamisi kuni selleni välja, et subjekt hakkab tajuma tervikliku keskkonna nähtamatuid ning käega katsutamatuid aspekte - selle aistilist küllust, geograafilist ning kogukondlikku ajalugu, kohamälu tervikuna (vt alaosa „Mälu”). Sest flanöör, kelle vaatepunkti Pilter vahendab, ei ole lihtsalt külaline maastikul, kes seirab üksnes geograafilisi mõõtmeid, vaid ümbrus saab talle iga sammuga isiklikumaks, kodusemaks, ta õpib mingeid keskkonna komponente eelistama teistele ning tema topograafiline visioon lähtub kindlatest meelelistest elamustest, mis põhinevad jalutaja siseilmal ja tahtel.

\section{Metsik ja võluv}

Pilteri teises raamatus „Retk Rahemäkke” tähistab sedasama piirkonda juba väljamõeldud nimi, subjektiivsete nüansside ja tähendusvarjunditega, tegelikust geograafiast hälbiv Airootsi (vt Pilter 2010: 11). Ehkki kohakuvand on raamatus põgus, ilmnevad selles põhilised tunnused, mida esiteks võib pidada füüsilise maastiku valikuliseks teisendamiseks loominguliseks ning teiseks annavad nende selektiivne esiletõstmine ja domineerimine Airootsi-nimelisele keskkonnale isiklikest aistilistest kogemustest lähtuva eripära ja omanäolisuse: Airootsi on metsik, niiske, ometi võluv ja meeldiv. „See, kuidas me näeme maastikku ja mida me seal näeme, on suurel määral seotud meie iluideaali ja ideaalmaastikega" (Plath 2014: 119), seega võib oletada, et Pilteri kirjanduslik ideaalmaastik sarnaneb selle Arkaadia-motiiviga, mida eespool sai iseloomustatud tokerja, hämara, ihade tumeda salu ja ettearvamatute elamuste paigana. See on küll igast küljest metsik ääremaa, ent kätkeb oma kolkalikus ilmes pigem ligitõmbavat ja leebet salapära: „...mulle meeldis Airootsi mahajäetud õhustik, kuhu me nüüd selle maakodu ostnud olime” (Pilter 2010: 139). 
Samaväärselt köidavad ka Airootsi rägud, siuglevate rästikutega, ent lopsakad metsad ja võsastuvad teeveered, nigelad kadastikud, vesised mätasmaad ja üleüldse rõhutatult niisked maastikud: koguni puude varjud ja hommikud on Airootsis niisked - ja seejuures „niiskelt paljulubavad” (Pilter 2010: 26, 28).

Et tegelikust keskkonnast on loodud just niisugune kuvand - perifeeria räämas ja rõske ilme põimitud meeldivuse ja kütkestavusega -, teeb Airootsist kogu oma rohtunud jalgradade, metsikuse ja niiske hõnguga subjektiivse paiga: omailma, mille iga subjekt loob iseendale sihipäraselt oma meelte, soovide, valikute ja püüdlustega. Omailmani jõudmist ja selle valmisolekut tunnistab võtmeline episood raamatus „Aerudeta köisraudteel”: „1991. aasta sügisel üritasin ma põgeneda Eestist Valgatabalvesse, kus kõneldakse lõunakorea keelt. Ma ei pääsenud sinna. [---] Siis tegin ma oma Valgatabalve Airootsist" (Pilter 2012: 153). Niisiis ei esitleta Airootsina ainult isiklikku vaadet ümbrusele, vaid sellest on kujundatud piisavalt turvaline ja hubane ruum, et sinna sulguda või kogu välise maailma üleliigsuse eest pageda - sellest on saanud personaalne eraldumispaik. Semiootilist omailma kui suletud üksust on piltlikult kirjeldatud seebimullina, mis jääb ligipääsmatuks kõikidele teistele peale selle keskse subjekti ning milles igal tegeliku maailma elemendil on ainult sellesse piiritletud ruumi ja selle subjekti tajuvälja kinnistunud tähendus ja tunnused (Uexküll 2012: 200). Iga omailma aluseks on küll tegelik füüsiline ümbrus, ent see ei vasta kunagi ulatuselt ega tunnustelt üksühesele reaalsusele, sest omailma moodustamise tuumaks on subjektiivne valikuprintsiip: ümbritsevast keskkonnast valitakse välja need komponendid, omadused ja aspektid, mis on igaühele olulised just temale antud ajas ja tema siseilmast lähtuvalt. Kusjuures kindlad tähendused igale objektile või kohale omistab iga subjekt ise (Uexküll 2012: 321). Pilter on ääremaise piirkonna tunnustele lähenenud sümpaatia ja meelelise rahuloluga, mis võimaldab ümbritsevat laotust hinnata just niisugusena, nagu ta on, ning ääremaisus ei tähenda eemaletõukavust ega lootusetust, vaid pigem kogemuslikku küllust ja ainulaadset maastikutaju. Pilteri tegelase lemmikuks on koht, mis kätkeb endas kõiki alg-Arkaadia metsikuid ja ebaõdusaid omadusi: „...metsistunud puiestee pikkade kadakarivide vahel, rohtunud rada, mis ligi kilomeetri jagu ulatus meie aiast mere äärde. Sellel teel võis kohata rästikuid, sattuda lambakorjusele või jääda vastasseisu hulkuva punase lehma või pulliga, kadakate varjus ääristasid teed suured maakivid, mis saja aasta eest olid põldudelt kogutud ja lihtsaks müüriks seatud" (Pilter 2012: 6).

On tähelepanuväärne, et niisuguste aistiliste ning emotsionaalsete elamustega kaasneb rahulolu ja leebus, mitte õõv ega rahutus, mida metsik ääremaa võiks kätkeda - Airootsi kujutamises on ühest hetkest pärit meelelised elamused võimelised mõjuma ka mingis muus kogemuses, andes viimasele nõnda ehk positiivsema ja helgema kuma kui muidu. ${ }^{5}$ Näiteks on selliseks aegadeüleseks aistinguks pärnaõielõhn, mille „rahu ja mahedus” on alati, ka südatalvel jutustaja ümber, „[s]iinsamas, Nislepa saludes” (Pilter 2010: 133). „Loodusilu esineb ilusaimalt vaid siis, kui on olemas sügavaimad suhted vaatleja ja objekti, tunnetaja ja ümbruse vahel” (Kant 1999: 20). Sellistest sügavai-

${ }^{5}$ Sama aspekti võib täheldada Tõnu Õnnepalu kirjandusliku omailma, Paradiisi juures, mis on muutlik ning mille tagasivaateline kujutamine nihutab aegruumilise terviku tunnetusskaala helgemale ja rahulikumale poolele, kui see paistis vahetult (vt Melts 2014: $518-521)$. 
matest suhetest andis kahtlemata tunnistust juba „Lohejas pilv”, kui metsik lopsakus hakkas tasapisi, kogemuste võrgustiku avardudes ning kodusemaks kõnnituna, võtma leebemat ja turvalisemat ilmet, millesse mahtus kõige rägu kõrval ka imetlusväärset „vormikat haljust” ja „eksootilist värvidegammat” (Pilter 2004: 175, 185). Hiljem on sügavaid elamusi rikastanud veel vertikaalsuse haaramine isiklikku ruumi ning vaatepiiri avardamine, mis nõuab kirjeldustelt meelelist erksust, teravdatud aistingute põimingut:

Läänetaevas lõõmav punane valgus voogas üle sini-halli-triibulise valendiku ja mattroheline jää siledaks aetud sõidurajal läikis ning säratas veel õrnalt. Lagendikku kauguses piiravad metsa- ja pargipuude viirud mustendasid valge karra all sõbralikus osadustundes. Leekiv loojang sisendas tunnet millegi pidulikust, igavesest ja valutekitavalt ilusast lõpust. Kare õhk, matid ja kiiskavad värvitoonid.... (Pilter 2014: 130).

Iga omailma eripära sõltub otseselt subjekti meelelisest avatusest tegelikule keskkonnale, tema nägemisvõimest, lõhnatajust, hääletoonide tabamisest, puudutustundlikkusest - igaüks reageerib ju sellele ja märkab ümbrusest seda, mis äratab mingil põhjusel huvi, mis ilmutab subjekti jaoks määravat tähendust ja on vajalik. Sest meel, mida suunavad tunded ja inimese siseilm, annab subjekti tähelepanuvõimele erinevaid suuniseid ja see seletab omailmset kirevust: „Leidub inimesi, kes püüavad leida loodusest midagi lüürilist, teisi, kes otsivad sealt midagi heroilist või jutustavat ja saavadki vastavaid muljeid. Nii on mõned omailmad põhijoontes ilusad, teised üllad, kolmandad jällegi melanhoolsed, ja kahjuks on väga paljud inetud" (Uexküll 2012: 202). Seda tõendab eriti geograafilise Noarootsi kahe kirjandusliku kujutuse kõrvutamine artikli järgmises alaosas.

\section{Erinevus}

Kõnekas paralleel Airootsile on üks hoopis teistsugune maastikukogemus, mille leiab Sigrid Rausingu dokumentaalsest mälestusraamatust „Kõik on suurepärane" (2014). Nimelt kattub selle raamatu tegevuskoht äratuntavalt Pilteri loomingulise Noarootsi/Airootsiga, osaliselt kattuvad kummagi kirjutaja maastikukogemused ajaliseltki - ja enamgi, nii Rausing minajutustajana kui ka Pilteri tegelane Lavran „Lohejas pilves” (ja kui loomingut-elulugu põimida, siis kirjanik Pilter isegi) on olnud inglise keele õpetajad samas Noarootsi koolis. Rausingu kohakujutuse keskmeks on Pürksi küla Noarootsi poolsaarel, mis on (anonüümsena, nimetamata) üheks fooniks ka „Loheja pilve” ühele tegevusliinile ja mis jääb vaid mõne kilomeetri kaugusele Pilteri järgmistes teostes esineva Airootsi põhipunktideks olevatest Einbist ja Österbyst. Viimaseid külastab ka Rausing. Avaramas ümbruses on niisiis mõlema autori ning nende kujutatud (mina)tegelaste teede ristumine ja maastike kattumine vältimatu. Faktipõhisusele ja tõetruudusele vaatamata on igasugune, ka Rausingu kirjeldus siiski sümboolne representatsioon ja subjektiivne tõlgendus, samamoodi lähtub Pilteri kirjanduslik ruum ja sellest aegapidi kujunev omailm äratuntavalt tegelikust geograafiast, mistõttu ei ole nende kahe kõrvutus mitte ainult õigustatud, vaid köitevgi just kirjanduslikke omailmasid uurides. 
Sest keskkondlikule samasusele vaatamata on kahe kirjutaja muljed piirkonnast huvitavalt erinevad.

Rausingu raamat vahendab Noarootsi kooli aastaks inglise keele õpetajaks läinud võorramaalase pilku, kelle tegelikuks eesmärgiks on antropoloogilised välitööd endise kolhoosi aladel, et hiljem kodumaa mugavustsooni naasnult kirjutada sellest doktoritöö. Seetõttu ei lähtu ta vaatlused ümbrusest kunagi sulandumissoovist või, osundades veel kord Heideggerile, üksinda ümbruskonna üksikasjade olemuse avarasse lähedusse liibumisest: Rausing kui kirjeldaja ei lähe poolsaarele selleks, et jääda ja avastada ning keskkond enda jaoks koduseks tunnetada (nagu Pilteri maastikel jalutaja), vaid ta jääb lõpuni distantsi hoidvaks võõraks, põgusaks külaliseks, kes teadvustab üha oma kohal viibimise ajutisust ja viimaks kätte jõudvat lahkumishetke. Geograafid teavad, et „igaüks ei mõista maastikku lugeda: võõrad ei tea konteksti” (Palang 2008: 16) ning et maastikku saab aduda kaheti, igapäevase tegevuse areenina ja vaateväljana või pildina: „Esimesel juhul me tunneme ümbruskonda, meil on oma teadmised, mälestused, sümbolid, väärtushinnangud, millest juhindudes me tegutseme. Teisel juhul on maastik võõras, kellegi teise oma, turismiobjekt: me tuleme kohale, oleme natuke ja läheme ära tagasi" (Palang 2008: 44). Nii pole parata, et kõrvaltvaataja positsiooni määratud Rausingule jäävad külalise vaatlevad silmad, mis ei võimaldagi pealismuljest läbi tungida ja näevad ümbruskonda võõristust tekitava pildina: ${ }^{6}$ kui Rausing ka võtab ette jalutuskäigu temale tuttavate põhjamaiste puude vahel, siis paradoksaalselt ei tähenda see tuttav tunne õdusat kodusust, kui üldse, siis äärmisel juhul on selleks kodususeks „sügavam, suurem ja kurvem versioon” kunagise kodu maastikust (Rausing 2014: 66). Ammugi ei avasta ta seal loovalt pulbitsevat mitmekesisust ja kõiki meeli köitvat metsikust nagu Pilter, vaid üksnes ühetoonilise „traagilise maastiku” (Rausing 2014: 19), „lihtsalt hooletusse jäetud ja unustusse vajunud" ja just seetõttu pelutavalt, ebaloomulikult metsiku paiga (Rausing 2014: 66). Meenutagem ja rõhutagem, et Ristikivigi omistas mulje Läänemaast kui „maailma kõige sügavamalt melanhoolsest maastikust” just „võõrale rändajale” (Ristikivi 1996: 24).

Kahe maastikukuvandi erinevus joonistub välja juba ainuüksi kohtade läbimise viisis. Pilteri jalutaja, laenates sõnu jällegi Ristikivilt, on kui „rändaja [kes] põlgab sirget tolmust maanteed ja sellele eelistab rohtunud metsarada" (Ristikivi 1961: 7). Ta astub Juulius Kilimiti kombel ümbruskonna sügavuti ja mitmeplaaniliseks tunnetamiseks just kruusateelt kõrvale: metsamassiivi ja sellest läbi, üle põldude ja läbi võsastike, pelgamata eelistada otsemaid teid ka siis, kui need kulgevad „natuke üle kilomeetri rannaäärset kadastikku pidi,

${ }^{6}$ Selle raames on väga tähenduslikud kaks kohakujutuse algust. Rausing alustab oma raamatut just nimelt pildist, fotost: „Minu ees on 1993. aasta talvel tehtud foto: keset lumist põldu seisab lagunenud küün, lumel peegeldub sinine, õige õrnalt oranžikas pärastlõunane taevas. See põld asub Eesti läänerannikul, kõigist keskustest kaugel äärealal, ühe endise kolhoosi territooriumil. Lagedal põllul paistab küün üksildane ja veidi melanhoolne. Ta on üle elanud sõja, maareformi, kollektiviseerimise ja nüüd ka erastamise” (Rausing 2014: 13) ning fotolikku vaatevälja jääb kinni terve raamat. Pilter aga alustab jutukogu „Vilekoor ja teisi jutte" ümbruskonna ajaloolisest tundmisest, isiklikult kohal olemisest ja juba teises lõigus intiimselt tunnetatud miljööd ahendades süveneb ta mälestustesse ning sümbolitesse ja sätib oma vaatepunkti inimeste argielulise areeni viimsele veerele, nimelt surnuaiale (vt Pilter 2014: 9-10). Muide, sarnasel viisil kodumaastikke kaardistav ja reaalsest keskkonnast omailma vormiv Andrus Kasemaa on samuti seadnud Poeedirahuks nimetatud isikliku ruumi ja selle kogukonna üle mõtisklemise üheks punktiks surnuaia (vt Kasemaa 2012: 11). 
kus teed tõkestasid okastraadid, võis kohata lehmi ja pulle ja sattuda lehmasõnnikule" (Pilter 2004: 72). Ja nii tajubki ta maastikku kõige erinevamatel viisidel, nii metsikult-süngelt, romantiliselt kui ka võrgutavalt-eksootiliselt ja igal juhul eeskätt loodusliku täiusena. Ta leiab sellesama kõrvaleastumist ärgitava tolmuse tee ning „roostikest ja vesistest mätastikest peaaegu ligipääsmatuks muutunud" mere vahelt metsast koha, kus taandub võsa ning maapind kumerdub küngasteks ning kus on aastaringseid metsloomaradu, sõra- ja käpajälgede oletuslikku vendlust (Pilter 2010: 71). Selsamal maastikul on ka erinevate andide küllust: „Meie kodu kõrvalt algav Eimbe mets oli suur ja lai. See oli täis mustikaid, sinikaid, vaarikaid, maasikaid, piibelehti ja sõnajalgu. Seal oli nätskeid ja madalaid alasid, seal oli kaasikuid ja männikuid, põlendikke ja raiesmikke ja kõrgete hõredate männipuudega metsaaluseid, kus alustaimed moodustasid tohutuid mättaid" (Pilter 2012: 164). Seevastu Rausingu jutustus püsib just sirgel tolmusel maanteel või „,[t]olmuste sillutamata teede ääres" (Rausing 2014: 16) ega näe ebaloomulikult metsistunud majalobudike taga loomulikku puutumatust. Nii on viimasel juhul jäänud keskkonnatajust välja mets kui ümbruse omaks/koduseks/isiklikuks jalutamise võimalus, mets kui borgeslik „hargnevate teede aed”, mida on kirjeldanud ka Eco ja mis sobib hästi Pilteri uitlemisepisoodi tuumaks: „Isegi kui metsas ei ole hästi sisse tallatud teid, võib igaüks omaenda tee välja joonistada, otsustades mööduda mõnest puust paremalt või vasemalt ja tehes valikuid iga vastutuleva puu puhul" (Eco 2009: 13) - Pilteri tegelane seda teeb, orienteerub sihipäraste valikute alusel ning kujundab niiviisi keskkonnast subjektiivse omailma.

Ajutine elanik ei suuda ümbritsevat mõista (vt Rausing 2014: 145) ja Rausing laseb kirjeldataval vaateväljal täituda eeskätt negatiivsete ja masendavate aspektidega: see oli kauge, primitiivne ja võimalik et isegi ohtlik kant, kus elu kujundasid „külm ja pimedus” ning elanikud olid vaesed ja vanad, „tühja pilgu ja mustuvate hammastega" (Rausing 2014: 17, 61, 132); tunded, mida ümbruskond temas tekitas, olid ärevus, ebakindlus, hirm, vastikus. Kui Rausingu pilgus on sealsed talumajad kõledalt mahajäetud, aegamisi metsistuvad ning lagunevad (Rausing 2014: 16-17, 59), siis Pilteri pilgus on needsamad majad pigem oma keskkonnaga harmoonias, umbes nagu leidis Läänemaa mitut palet märkama hakanud Ristikivigi, osutades igat kasvamisvõimalust, ka majade rookatuseid kasutavale samblale, „...kui hästi sobivad siinse loodusega muidu nii primitiivseina tunduvad taluehitused" (Ristikivi 1996: 25). Ajutine, „võõras rändaja” näeb kobaras „porisevõitu ja hallide rookatustega puumaju, millele mõnikord oli kehvadest tellistest müürijuppe toeks laotud" (Rausing 2014: 16), ning tajub küla esteetikas arhitektuuri piiratust, hääbumise pidevust, katkendlikkust ja nihestatust - see on „mälu ja narratiivide kao esteetika" (Rausing 2014: 145-146). Pilteri maastikukuvandis aga puudub seesugune kriitika ning maastikku tajutakse osadustundega, humaanselt ja igal juhul eluliselt - needsamad majad ei ole mitte õõvatunde allikaks, vaid Pilteri tegelane näeb neid hoonetena, kus elavad või elasid kunagi oma kulgemisega tähelepanu väärivad inimesed. Ehk teisisõnu, lisaks kontekstuaalse rütmi ja tingimuste mõistmisele vaatab ta fassaadist läbi, astub sarnase sammu, mida Eco on ühel juhul kirjeldanud liikumisena topograafiast ajalukku ning vähehaaval sel maastikul elavate inimeste vaatepunkti omaksvõtmisena (vt Eco 2009: 86). Ja nii ei tähenda Airootsi mälu ja narratiivide kadu, vaid lausa vastupidi - nende alalhoidu. 


\section{Mälu}

„Maastiku üheks põhiliseks funktsiooniks on kanda edasi mälu, seda aga enamasti mitte palja ja halja faktide kogumina, vaid pigem puhastatud hingepeeglina" (Maiste 2011: 234). Pilteri Noarootsi-põhise kirjandusliku maastiku üheks tahuks on kahtlemata kohavaimu ja -mälu edasikanne subjektiivse hingeseisundi toel. Mälumaastikud ei ole aga algusest peale olnud osa Airootsi-kuvandist, vaid nendeni on jõutud pikkamisi, milleks iga teos on lisanud uue tahu - erinevate seikade jäädvustamine on käivitanud erinevaid meelelisi kogemusi ja meenumisi, mida omakorda rikastavad kõik järgnevad mälu aktiveerivad detailid, nii et mälu edasikanne maastikel saab nähtavaks kõikide teoste koosmõjul. „Lohejas pilves” tuli kõigepealt jõuda maakoduni, väljuda selle õuelt ja kaardistada ümberkaudsed objektid, õppides niiviisi lähemalt tundma nende objektide - olgu siis ligi saja-aastaste puude, vanade kiviaedade, kohalike tüüpide või millegi muu - aega, iga, konteksti. Seejärel sai leida erinevaid metsaradu ning neil uitlemisega vahetu ümbruskond enda jaoks kodustada, et siis jõuda veendumuseni sümpaatias ja meeldivustundes, mida koht parasjagu äratab. Kui vahetu keskkond oli saanud isiklikuks, avanes see eemalt aegamisi lähenenu vaatevälja kaudu ajaloo aimamisele.

Pilteri kohakujutuses saavad kokku mälu kaks tahku: geograafilise ajaloo tunnistamine ning mälestused inimestest, kes neil muutlikel maastikel tegutsenud. Varasemates teostes ilmneb ajalooline kohakuvand eeskätt peategelase perekonna Airootsi-elu jäädvustamises, üksikul juhul ka maastikuüksuste, näiteks lähedaloleva oja aastakümnetega kraaviks muutumise kirjeldustes, millesse on põimitud nii viited vanadele kaartidele kui ka kohalik pärimus (vt Pilter 2004: 172-173). Jutukogus „Vilekoor ja teisi jutte” ilmnevad erinevad ajakihistused geograafilise ja kogukondliku mälulõime veelgi hoolsamas põimingus. Maastikukirjelduste lähtepunktiks seatakse kohe esimesel leheküljel selle nüansi rõhutamine, et kogu Airootsi (nagu ka Noarootsi) oli kunagi saar ning loodus on säilitanud märke sellest siiani; ${ }^{7}$ samas seotakse kunagise mandrist eraldatuse tunnusmärgid sealse rahva kõnepruugi ja harjumustega: paari sajandi eest mereväinaks olnud ja nüüd kidura pruuni taimestikuga luhamaad olid rannarootslased harjunud pidama niiskeks, millekski kõlbmatuks ahermaaks ning nimetasid seda eriskummaliselt Atlandiks (Pilter 2014: 9).

Niisugusest avarast lähtepunktist hakkab Pilter oma lugudes maastikupilte järjest ahendama, tungima mööda jalgradu sügavamale tihnikuisse, märgates nõnda jäänukeid aegadest, mis jäävad väljapoole tema ja tema tegelase ajakogemust: lisaks endisele mereväinale osutatakse näiteks sellele, et Einbi metsa all on varjus kunagine nõmm (Pilter 2014: 16). Sügaval varjus olevate metsistunud jalgradade, rägusse mattunud nõmmede ning poolsaart kunagi mandrist eraldanud väina aimamine annab taas märku keskkonna subjektiveeritusest, ajakihtide omaks tajumisest - ning seda valikuliselt ja isiklike eelistuste põhiselt, sest põgusale pilgule vaevu nähtavatest aspektidest on moodustunud omailma rõhulised komponendid. Näiteks Rausing on küll märganud, et seal „oli kunagi olnud saar või koguni mitu” (Rausing 2014: 22), kuid ebalus „või koguni mitu” annab tunnistust geograafiliste teadmiste nappusest, isikliku perspektiivi puudumisest ning maastiku mõtestamise ahtusest. Mälu

\footnotetext{
${ }^{7}$ Poolsaart mandrist eraldanud väinastiku asemel on nüüd $8 \mathrm{~km}$ laiune riimveeliste jäänukjärvedega maakael (nn Sauemeri).
} 
jälgedest minnakse mööda, need märgitakse küll ära, aga neist ei moodustu jutustaja kohataju olulisi komponente, tema visuaalne selektsioon välistab need nüansid ning riivamisi silmatud, salajaste kihistusteta keskkond on vaid „lauge ja proosaline maastik” (Rausing 2014: 30). Nii ei teki sügavaid suhteid vaatleja ja objekti, tunnetaja ja ümbruse vahel, millele sai eespool osutatud kui loodusilu aimamise eeldustele, ja koha kirjanduslik representatsioon jääb subjektiivselt tähendusliku (aja)mõõtmeta, seal laiutab unustus. Seevastu Pilteri kirjeldused - mälu edasikanded - näitavad Airootsit pigem poeetilises ja aistilises külluses, millise võimaluse annab selle uurimine kiht-kihilt ja samm-sammult aja(loo) ja ruumi tervikus.

Maastikumälu hoomamine tähendab ka leida midagi „põliselt läänemaist - sellele vaesele, ahtrale, lausikule, märjale ja madalale maakohale omast" (Pilter 2014: 93) - sellise määratlusega viipaks Pilter justkui Läänemaad otsinud Ristikivile. Põlist läänemaisust aga kannavad Pilteri omailmas ääremaise ümbrusega korreleeruvad inimtüübid, niisiis Airootsi kui loomingulisse omailma kuuluvad inimesed, „vahemaid ja heitlusi läbinud” ja pead püsti hoides „teotsenud” (Pilter 2014: 10) - needsamad, keda nimetati juba „Lohejas pilves” koduümbrust kaardistades (vt alaosa „Kohale jõudmine”). Nimetamisest aga on „Vilekooris...” jõutud kaugemale: neid on tundma õpitud ning millegi poolest tähelepanuväärsematest on visandatud väikesed elulood või biograafilised fragmendid: ühe omailma sees saavad endale kirjandusliku hingamise näiteks rannarootsi juurtega endine põllumees, traktoristist külanaaber ehk Veemees, tragi ja uuendusmeelne Siberis sündinud maanaine, peenraid ja banaane hindav põliselanikust naabrinaine, tegelase (ja samahästi kirjaniku) enda vanemad ja vanavanemad... Nende igapäevaelu juhtumuste ja toimetamiste kaudu esitletakse valitud aspekte Airootsi minevikust, muutuvatest maastikest, suursugusest loodusest, olmemuredest, püsivatest kommetest. Inimeste lugusid hoiab koos selge ja ometi subjektiivne maastikuline raam, mille verstapostiks on ühest servast kujundlikult Atlandiks nimetatud luhamaa (mis nüüd hoiab poolsaart maismaa küljes), teiselt poolt aga juba konkreetne meri - ning kogu vahepealne ala on see mentaalne ruum, milles sulanduvad elud ja maa („Nad elasid, nagu elab huumus”, Pilter 2014: 10), ajad ja ruumid, isiklik ja kollektiivse mälu valitud üksused, tegelik geograafia ja belletriseeritud maastikud.

\section{Kokkuvõte}

Oma loomingus on Lauri Pilter kujundanud Noarootsi poolsaare põhjal endale kirjandusliku omailma, millele on pärast esikteost antud kirjanduslik toponüüm - Airootsi. Tegeliku poolsaare kujutamine, nii kohtade kui ka inimeste äramärkimine ja iseloomustamine, loodusmuljete visandamine ja ulatusliku tervikpildi loomine avaldub tema neljas teoses erinevalt, maastikku süvenetakse etapiliselt ning Airootsini jõudminegi on Pilteri loomingus toimunud etapiliselt. „Lohejas pilv” kujutab muude tegevusliinide seas Noarootsi saabumist, piirkonda kirjeldatakse pisteliselt ning lihtsalt ja avaralt Noarootsina, ilma toponüümse ümberütlemise või poolsaarest ahtama ala märkimisväärse nimetamiseta. Selgelt subjektiveeritud ümbruskonnatunnetuse ning isikliku omailma äratundmiseni ollakse alles teel. Omailma, mis on füüsilisele 
keskkonnale otseselt taandamatu, kujundab objektiliste suhete võrgustikuga võrdselt ka kogemuslik tervikstruktuur (Deely 2009: 23) - kui „Lohejas pilves” on tegu veel laialivalguvamalt tunnetatud, ent selgelt Noarootsiga, mille kogemuste võrgustik pole veel piisavalt intensiivne selleks, et moodustada omailma, siis aegamisi Pilteri tegelane loob endale kogemuste võrgustiku, mille peamiseks viisiks on emotsioone avav uitlemine, jalutamine läbi maastiku, ümbruskonna pisiasjaline ning meeleline kaardistamine. Seeläbi kodunetakse ja kohanetakse - erinevalt näiteks Sigrid Rausingu minajutustajast, kes jääb staatiliseks külaliseks. Ent just kohtade võrgustiku loomine, maastiku avastamine uitajana teeb võimalikuks selle, et Noarootsist saab juba „Retkes Rahemäkke" Airootsi, oma isiklik paik, mis võimaldab ühel ja samal maastikul kontrastseid aistilisi elamusi (nii nagu Ristikivi leidis Läänemaa otsinguilt korraga melanhoolse ja harmoonilise maastiku) ning mis avaneb subjekti tajuväljale ka ajalooliselt, nii et esialgu mööda looduslikke elemente kulgev objektiliste suhete võrgustik valgub aegamisi üle inimeste.

Tegelik keskkond on sellega igatahes teisendatud valikute ja eelistuste põhiseks, nähtava ja kujuteldava põiminguks. Kui Rausingu raamatus tähendas sellesama piirkonna mahajäämus, räämas ilme üheselt eemaletõukavat trööstitust ja masendavust ning süvendas distantsitunnet, siis Pilteri maastik on küll igast küljest metsik ääremaa, ent kätkeb siiski ligitõmbavat ja leebet salapära, mida võib tõlgendada oma isiklikus omailmas sügavuti kohalolemisena. „Vilekoor ja teisi jutte” on selgelt fookustatud üksnes Noarootsi/ Airootsi kõige olulisematele ja vajalikumatele aspektidele (olgu nendeks siis jalgrajad või kohalikud elanikud), mida on aja jooksul tundma õpitud. Ka geograafilist eeskuju on kitsendatud põhiliselt kaheks külaks: „Vilekoori...” Airootsi tähendab ennekõike poolsaare servapealseid külasid Einbit ja Österbyt, samanimelistena nii ilukirjanduses kui ka tegelikkuses. Tuntav kohakujutuse ahendamine kõige äärmisemate külade kujutuseks tähendab ühtlasi seda, et trajektooride visandamisel on üsna sihikindlalt välditud nii palju kui võimalik ümbruskonna keskset küla (Pürksit), mis (anonüümsena) oli üheks põhiliseks tegevuspaigaks veel „Lohejas pilves” - viimaks on see, mis esikteoses oli „maakodus käimise” põgus sihtpunkt, saanud isikliku ruumi keskmeks ning kohalikes mõõtmetes tsentri-perifeeria opositsioon on omailma jaoks ümber mängitud.

Ning Airootsiks ümber nimetatud piirkond kannab selgelt subjektiivse omailma tähendust. Nii et kokkuvõtteks pädeb artiklis vaadeldud Noarootsikuvandi kohta see, kuidas on mõtestatud maastikku: „Maastik on meie valikute ja eelistuste tulemus, niisama võrra kultuuriline autonoomia kui meelte oaas, intellektuaalne kontseptsioon ja subjektiivne kaemus, tähistades mitte igasugust ümbritsevat pildist välja rebitud tükki [---], vaid ennekõike meie kujutlust sellest, silma ja meelte poolt vastu võetud ja mõistuse poolt korrastatud kultuurilist paradigmat, mille puhul esteetika diktaat kehtestab prioriteedi maastiku teiste ja kahtlematult oluliste kvaliteetide ees" (Maiste 2011: 22-23).

Artikkel on seotud grandiga nr ETF9035 „Adressaadi dünaamika eesti elulookirjutuses". 


\section{Kirjandus}

D e e l y, John 2009. Semiootika alused. (Tartu Semiootika Raamatukogu 4.1.) Tartu: Tartu Ülikooli Kirjastus.

E c o, Umberto 2009. Kuus jalutuskäiku kirjandusmetsades. Tlk Ene-Reet Soovik. Tallinn: Varrak.

H e i d e g g e r, Martin 1989. Loov maastik: Miks me jääme provintsi? Tlk Ülo Matjus. - Akadeemia, nr 2, lk 293-296.

K a n t, Edgar 1999. Matkamisest ja rändelust. - E. Kant, Linnad ja maastikud. (Eesti mõttelugu 28.) Koost Ott Kurs. Tartu: Ilmamaa, lk 15-23.

$\mathrm{K}$ a s e m a a, Andrus 2012. Leskede kadunud maailm. Tallinn: Varrak.

K r o n b e r g, Janika, M e l t s, Brita 2012. Karl Ristikivi rändav Arkaadia. - Keel ja Kirjandus, nr 10, lk 721-733.

L a g m a n, Edvin (toim) 1964. En bok om Estlands svenskar. 2. Ortnamn och terrängord. Jordbruk och boskapsskötsel. Sjöfart och fiske. Livets och årets högtider. Stockholm: Kulturföreningen Svenska Odlingens Vänner.

M a i s t e, Juhan 2011. Kolmas silm. Essee ilusast maastikust. Tallinn: Varrak.

M e l t s, Brita 2013. Poeedirahu - Andrus Kasemaa kirjanduslik omailm. - Keel ja Kirjandus, nr 6, lk 393-408.

Melts, Brita 2014. Paradiis - Tõnu Õnnepalu kirjanduslik omailm. - Keel ja Kirjandus, nr 7, lk 509-524.

N i r k, Endel 1991. Teeline ja tähed. Eurooplase Karl Ristikivi elu. Tallinn: Eesti Raamat.

O j a, Tõnu 2008. Millest tekib maastik. - Vikerkaar, nr 7-8, lk 123-129.

P al a ng, Hannes 2008. Kümme. Koos kogetud maastikud 1997-2007. Tallinn: Argo.

Pil t e r, Lauri 2004. Lohejas pilv. Romaan lühijuttudes. Tallinn: Tuum.

Pil t e r, Lauri 2010. Retk Rahemäkke. Tallinn: Tuum.

Pil t e r, Lauri 2012. Aerudeta köisraudteel. Charleston-Tartu.

P i l t e r, Lauri 2013. [Järelsõna.] - Sarah Orne Jewett, Hõbehaigur. Tlk L. Pilter. - Akadeemia, nr 1, lk 13.

P i l t e r, Lauri 2014. Vilekoor ja teisi jutte. Tallinn: Tuum.

Pl a t h, Ulrike 2014. Aistilised maastikud. Meelelised reisid Baltimaadesse 17501850. - Maastik ja mälu. Pärandiloome arengujooni Eestis. (Acta Universitatis Tallinnensis. Socialia.) Koost, toim Helen Sooväli-Sepping, Linda Kaljundi. Tallinn: Tallinna Ülikooli Kirjastus, lk 111-145.

R a u s i n g, Sigrid 2014. Kõik on suurepärane. Mälestusi Eesti kolhoosist. (Imeline Ajalugu.) Tallinn: AS Äripäev.

R i s ti k i vi, Karl 1961. Põlev lipp. Lund: Eesti Kirjanike Kooperatiiv.

R i s t i k i vi, Karl 1996. Läänemaad otsimas. - K. Ristikivi, Viimne vabadus. (Eesti mõttelugu 7.) Koost Janika Kronberg. Tartu: Ilmamaa, lk 23-27.

R i s tiki vi, Karl 2008. Rohtaed. Neljas trükk. Tallinn: Pegasus.

Ru uts o o, Sirje 1988. Vergilius, Ristikivi ja P.-E. Rummo Arkaadia teel. Ühe motiivi tunnetusliku tõlgenduse võimalusi. - Karl Ristikivi 75. Karl Ristikivi 75. sünnipäevale pühendatud konverentsi materjalid II. 4. detsember 1987. Tallinn: Eesti NSV Kirjanike Liit, lk 75-87.

S c h a m a, Simon 1995. Landscape and Memory. New York: Alfred A. Knopf.

U e x k ü 1 l, Jakob von 2012. Omailmad. (Eesti mõttelugu 105.) Koost Kalevi Kull, Riin Magnus. Tartu: Ilmamaa.

V e l s k e r, Mart 2014. Airootsi raamat. - Sirp 24. X, lk 24. 
Keywords: Lauri Pilter's oeuvre, Noarootsi peninsula, literary mindscape, Umwelt, landscapes in fiction, literary geography, autobiographical approach

Ever since his first book Lauri Pilter has associated his narratives with personally meaningful places. Gradually his interlacing of fact and fiction has caused a network of real places develop into a literary mindscape fictitiously called Airootsi. In real landscape its counterpart could be seen in the Noarootsi peninsula, Western Estonia. Noarootsi is also the initial name of Pilter's mindscape. Gradually, however, some odd place names start appearing, which blurs the possible correspondence between literary and real geography.

In the framework of different interpretations of landscape, literary mindscape and Umwelt, the article analyses the literary mappings of Noarootsi and the gradual transformation of the area into the fictitious Airootsi in Pilter's oeuvre. Four Pilter's books are examined, namely, three novels in stories: Lohejas pilv („Dragonish cloud”, 2004), Retk Rahemäkke („Up to Mount Rahemägi”, 2010) and Aerudeta köisraudteel („On a funicular railway without oars”, 2012), and the collection Vilekoor ja teisi jutte („The booing chorus and other stories”, 2014). Pilter's portrayal of the Noarootsi peninsula, his choice of places and characters, his rendering of natural impressions, down to the attainment of an extensive overall view, differs across the four books, deepening step by step on the way to his personal mindscape. The aim of this study is to explicate how visual selection and purpose are at work in the literary rendering of a real landscape, how that landscape develops into a mindscape, what its main features are and how Pilter's character goes about creating his own network of experience. This network is manifested in emotional rambling episodes, where the surroundings are mapped in great detail and very sensuously, which is exactly how a real landscape, renamed as Airootsi, is transformed into a personal mindscape.

Brita Melts (b. 1984), MA, doctoral student at the Institute of Cultural Research and Fine Arts, University of Tartu, brita.melts@ut.ee 